Article

\title{
Estimates of Soil Renewal Rates: Applications for Anti-Erosion Arrangement of the Agricultural Landscape
}

\author{
Fedor Lisetskii $\mathbb{D}$ \\ Federal-regional centre of aerospace and surface monitoring of the objects and natural resources, Belgorod \\ National Research University, 308015 Belgorod, Russia; liset@bsu.edu.ru; Tel.: +07-4722-301370
}

Received: 7 May 2019; Accepted: 17 June 2019; Published: 20 June 2019

\begin{abstract}
Engineering and geographic substantiation of the anti-erosion organization of agricultural landscapes requires not only differentiated estimations of erosion losses, but also commensurate (in terms of space-time scales) estimations of the soil loss tolerance. The main approaches for determining the participation of estimations of soil formation in the substantiation of erosion tolerance have been defined. This study is aimed at justifying the methods of incorporating the results of pedogenesis modeling into computational methods for organizing agricultural landscapes. This paper presents the results of a study of the process of formation of the humus horizon and the accumulation of organic carbon in soils, based on soils from archaeological sites in the Crimean Peninsula over a period from 25 to 2000 years ago, with differences in climate and parent rock, in a region with a thousand-year history of human activity. The patterns of variation in the thickness of the humus horizons over time and the accumulation of carbon were determined, and estimates for the rate of the pedogenesis were obtained. In connection with the slowing of the rate of pedogenesis over time, the chronofunction of the change in the thickness of soils (of both exponential and logistic types) may be applied and, on this basis, it is possible to calculate the rates of the formation of the humus horizon depending on the morphological status of the soils. During re-naturation of highly degraded soils, maximum renewal rates may take place only with a very high input of organic matter, which is crucial to take into account in the development and implementation of programs for the rehabilitation of degraded lands. Under the conditions of slope agriculture, the rationale for T-values should be linked to many factors of the input and consumption of organic carbon, which provides a logical mathematical model of the formation of soil quality. For soil quality management on agricultural lands, a formula for calculating T-values, using an equation where the rate of pedogenesis is associated with a variety of changes in soil organic carbon, is proposed in this article.
\end{abstract}

Keywords: soil renewal rates; chronofunction; erosion tolerance level; management on agricultural lands; Crimean Peninsula

\section{Introduction}

According to modern requirements for resource-saving land use, the land is considered not only as a means of production, but also as a significant part of the global pedosphere which fulfils the most important biospheric and ecological functions. The standardization of soil erosion to the permissible limits of reduction of the top layer is closely related to the estimations of soil renewal rates, which differ significantly in individual soil-climatic regions. Soil loss tolerance (also known by "tolerance (tolerable) level", "T-value concept (tolerable soil loss)", or "erosion tolerance"), indicated by the T-value, is the most important parameter for monitoring the protection of soil in Europe and North America. However, a matter of decisive importance for planning and monitoring soil-protective and 
soil-restoring measures is the development of fundamental ideas about soil formation rates (first of all, for such important components of pedogenesis as the rates of formation of the humus horizon and organic carbon (Corg) accumulation) and the time-dependent patterns of these processes.

To define the T-value, three different approaches have evolved: economic and agronomic, soil-genetic, and ecological [1]. The first and second approaches are aimed at the preservation of the soil as a production resource and of its ecological functions, while the third one aims for, among other things, a reduction of environmental pollution.

From the point of view of using estimations of the rate of soil formation in the justification of T-values, the following classification of the available approaches may be proposed (Table 1), in which the following concepts are used: predicted rate of soil loss $(\mathrm{W})$ and the rate of soil formation (V).

1. $\mathrm{T}=\mathrm{V}$. Identification of $\mathrm{T}$-values with the rate of natural and/or anthropogenic soil formation, or as a direct function of these values; for instance, $\mathrm{T}=\mathrm{V}-\mathrm{W}$. In the conditions of a high soil-protective efficiency of plant cover, the T-values are made equal to the rate of normal (geological) erosion.

2. $\mathrm{T}=\mathrm{Wtol}$. The rationale for such a value of sediment yield is that it does not lead to a significant reduction in crop yields (Wtol is tolerance soil loss).

3. Approaches in which estimates of the rate of soil formation are included in the calculation methods for determining the T-values. In addition, the T-values may be conditioned by parameters, such as the predicted rate of soil loss, soil thickness, and humus reserves.

Table 1. The main approaches in determining the soil loss tolerance.

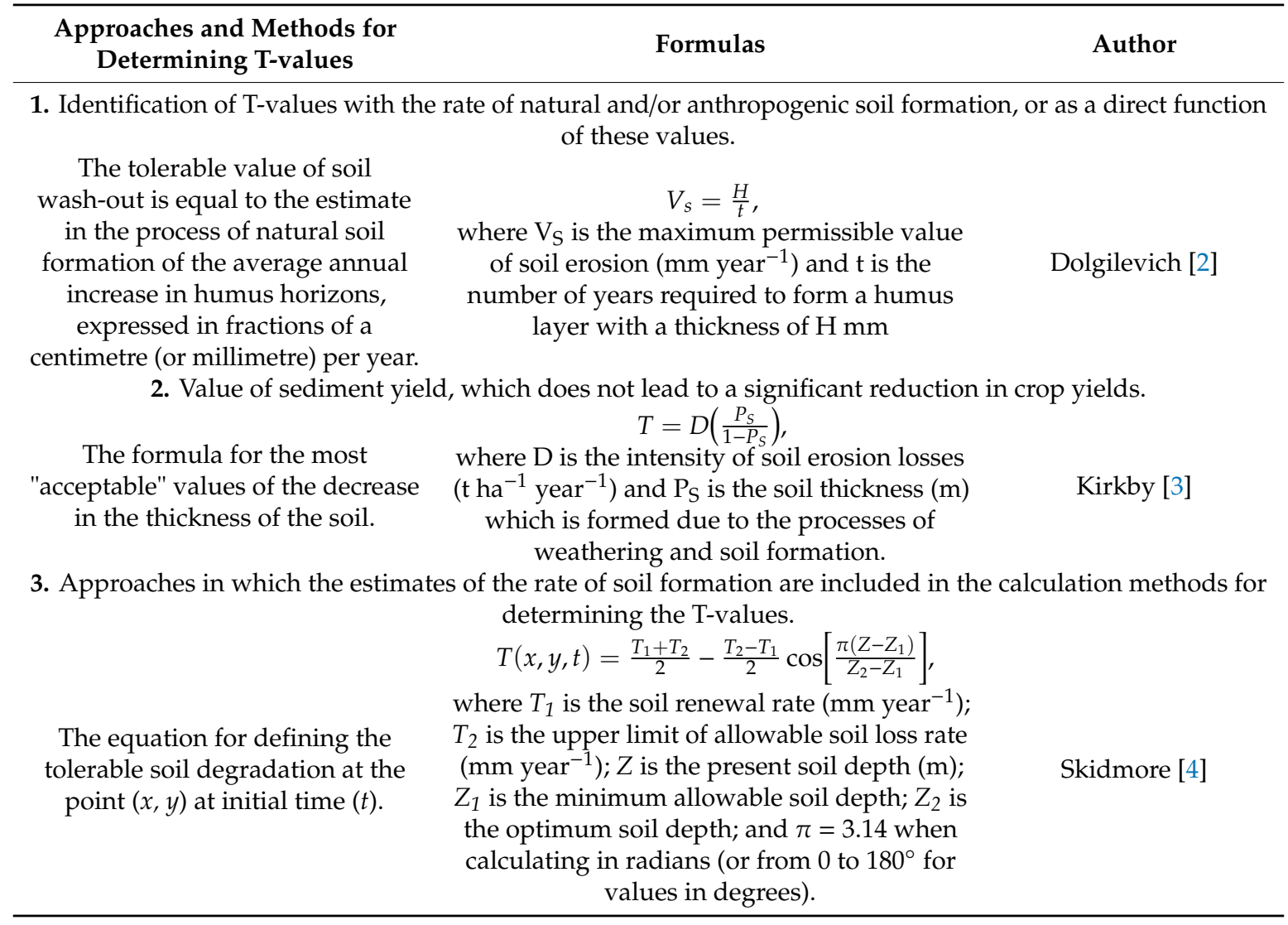


Table 1. Cont.

\begin{tabular}{|c|c|c|}
\hline $\begin{array}{l}\text { Approaches and Methods for } \\
\text { Determining T-values }\end{array}$ & Formulas & Author \\
\hline $\begin{array}{l}\text { Indicator of the potential duration } \\
\text { of the expenditure of soil with a } \\
\text { constant average annual soil loss } \\
\text { rate. }\end{array}$ & 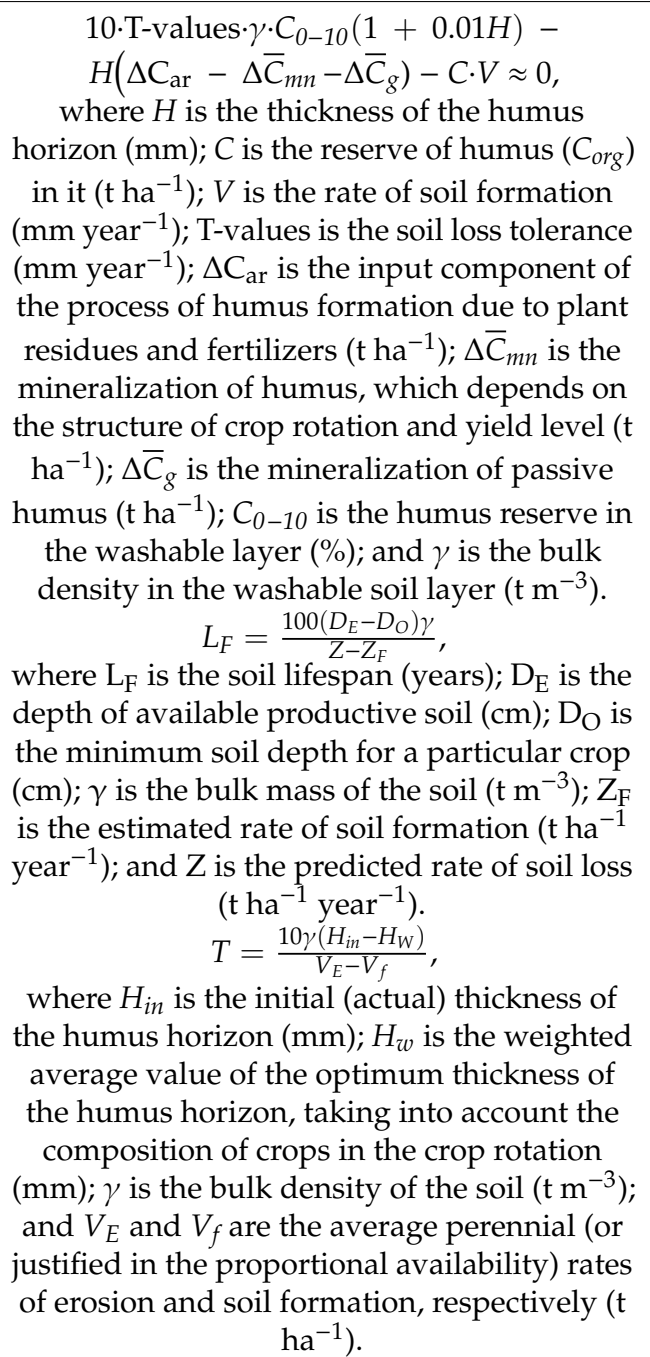 & $\begin{array}{l}\text { Elwell and Stocking [7] } \\
\text { (with modifications) }\end{array}$ \\
\hline
\end{tabular}

In Western Europe and North America, when analyzing approaches to modeling water erosion processes, either two- [9] or three-level [10] classification is used. Within the specified classes and sub-classes of the models, a further classification is possible [6], which details the models on other grounds; in particular, by classifying them as: (a) 0-dimensional (lumped), 1-dimensional (1D), or 2-dimensional (2D); and (b) implemented on a plot scale, slope scale, catchment scale, or a large territory (regional scale). Regretfully, a commensurate level of detailing the T-values is not yet available; however, the need to develop multi-level T-values is obvious. An approach for scaling the T levels has only recently been outlined, however. In general, we may speak about the two main levels of T-values: (1) T1: such a value solves the ecological-biospheric level of the problem, and the value of T1 is objectively determined by the soil renewal rates; and (2) T2: The value on the slope and catchment scales varies over a wide range and should be differentiated in as much detail as the calculated sediment yield value.

The soils formed in extra-glacial regions have a long history of development (over approximately the last 11,500 years) [11]. The "unfolding" of the pedogenesis history using the geoarchaeological approach has great informational potential; in particular, by analysis of the chronosequences and chronofunctions of soils, according to data that may be obtained both from daylight soils (soils that 
have formed between the beginning of the death of the monument and the present) and from buried soils at different archaeological sites.

After the initial studies on the rate of soil formation, which were based primarily on the history and an accumulation of the results of determining the specific activity of ${ }^{14} \mathrm{C}$ in certain fractions of the soil humus, a new stage in the development of soil formation research took shape. A rapid growth of data, due to active use of the soil-archaeological method of dating and study of the evolution of soils, took place, from the 1970s to present [12-14]. Moreover, unlike the first three decades, from 2000 to present [15-17], there has been an accelerated growth in the number of scientific publications. These papers used new geoarchaeological methods in the research of soils and sediments at archaeological sites [18-25].

It should be noted that, in the advanced geoarchaeology literature, much attention has been paid to the study of buried soils (see the review by Mitusov et al. [26]); while the daylight soils of archaeological sites have not been studied in depth. However, about 40 years ago, Gladfelter [27] stressed the prospects for geoarchaeological elaboration of approaches for differentiating cultural and natural features, including post-occupational disturbances by biological and pedological processes.

The use of soil-archaeological methods has significant advantages, in terms of the accuracy of the estimates and reliability of interpretation, if we study the chronosequences of the daylight and buried soils, instead of individual different-time soils. There is a need for high-quality profile datasets (e.g., chronosequences, climosequences, and toposequences). This type of dataset would surely provide a good test for soil evolution models [28].

As, initially, chronosequences and chronofunctions were presented only at a qualitative level (in the form of graphs and diagrams that reflected the nature of change in soil properties over time), later attempts were made to establish quantitative dependencies of the change in the morphology and properties of the soil on their age, using pedochronological data [29,30]. Lisetskii et al. [31] substantiated the feasibility of describing the zonal soil development process over time, using a family of S-shaped curves; in particular, using the Gompertz function. The formation of the humus horizon should be described by a model that reflects a gradual increase in soil renewal rates (proportional to the amount of organic matter); then, after reaching some maximum, the model should reflect a gradual deceleration of the soil formation rate, corresponding to the established equilibrium of the organic matter in the zone of the maximum concentration of soil biota in the substrate [31]. The Gompertz function adequately reflects these features. The graph of this function has an asymmetric form, due to the stretching of the upper branch, and so this function approximates well the trends of the soil formation profile, which is characterized by a slow increase in the humus horizon of mature soils.

The aim of this study is to substantiate the ways of integrating pedochronological data and estimates of the rate of soil formation into computational methods for arranging agricultural landscapes.

\section{Material and Methods}

The soil cover of the Crimean Peninsula (Figure 1) is represented by various types and sub-types (more than 50 species) of soil, the predominant types being Calcic Chernozem and Petrocalcic Chernozem [32]. The south coast of Crimea (SCC) exhibits a remarkable variety of soil types on various substrates; mainly Sub-Mediterranean cinnamonic soils and red types [33]. Calcaric Cambisols (IUSS Working Group WRB 2014) or, according to the nomenclature of Crimean soils, the cinnamonic forest soils, occur on the southern slope of the Main Ridge and in the foothills west and east of it.

These specific features determined the choice of four areas for our pedoarchaeological field studies (Figure 1). 


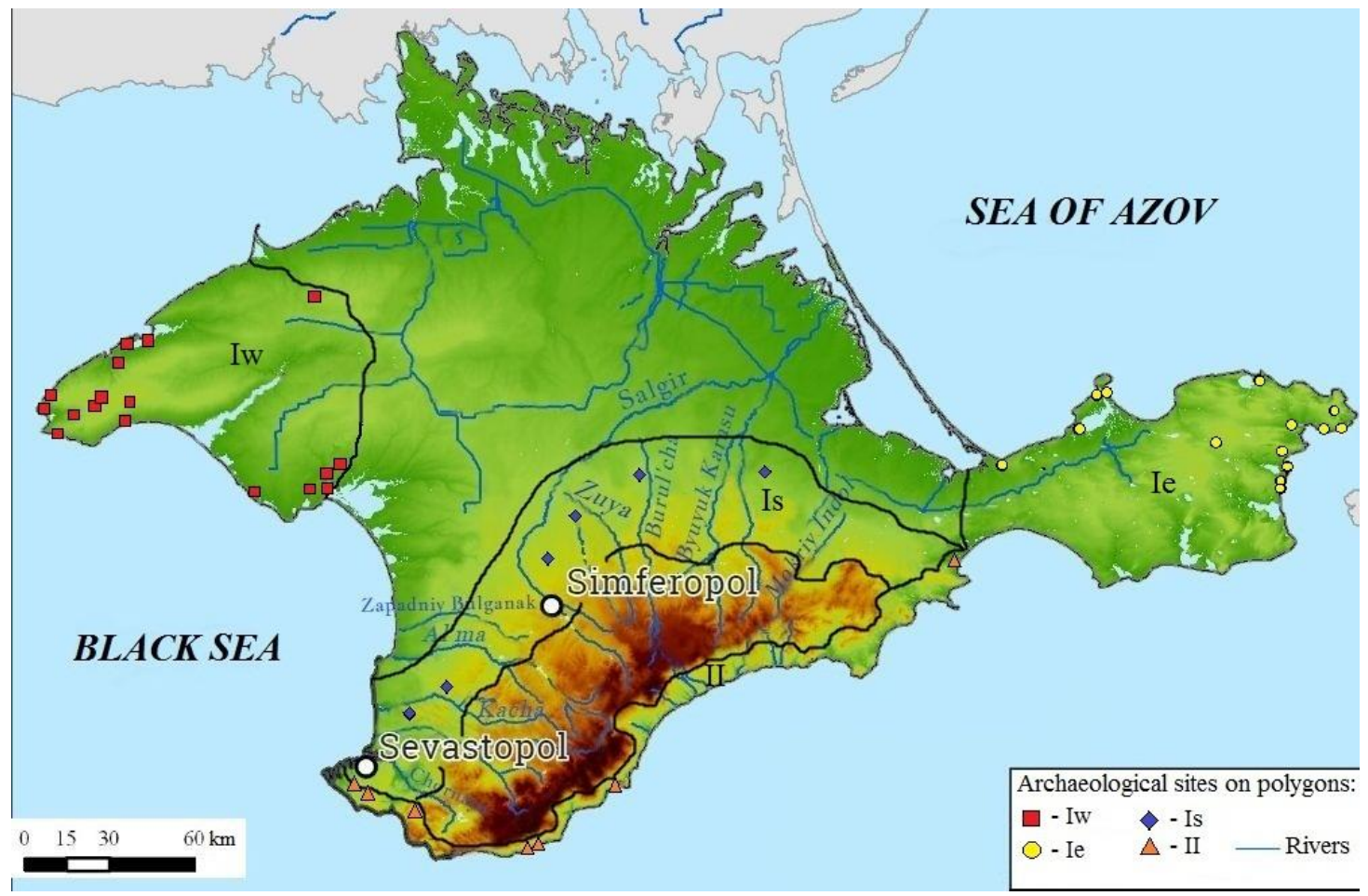

Figure 1. Archaeological sites (from which the studied soils are found) within the research polygons, in the territory of the Crimean Peninsula within the boundaries of the natural areas. I denotes the Crimean Plainland (West, East) and Foothills (South), and II denotes the South Coast of Crimea (SCC).

The soils studied were sourced from archaeological sites located on the Crimean plains (polygon I) and on the south coast of Crimea (polygon II). The field studies of the soils were conducted in 2012-2016 for determining the morphological structure and the soil properties, which were dated, based on historical and archaeological data, for the subsequent formation of chronosequences and chronofunctions for individual soil-climatic regions.

\subsection{Different-Time Soils of Archaeological Sites}

More than 150 objects (soils on archaeological sites) were studied; the key ones are shown in Figure 1. In the territory of the Crimean Plainland (polygon I), data were obtained on the thickness of the horizons $\mathrm{A}$ and $\mathrm{AB}$ in repetitions on 117 dated surfaces, including 36 objects aged (based on historical dates) 230 years and less; the rest were dated in a range from the 14th century B.C. to the 17th century A.D. For the particular conditions of the sub-Mediterranean climate (polygon II), the chronosequence members were 42 objects within the date range from 25 to 2000 years old. Some members of the chronosequence were the calcaric Cambisols, which were used to form the chronofunctions presented in previous pedological studies based on 21 archaeological sites [34,35], but were supplemented by the results of subsequent studies. The Munsell colour system [36] was used for the determination of soil colours. For evaluation of soil organic carbon (SOC), we used a method based on the oxidation of organic matter $\mathrm{K}_{2} \mathrm{Sr}_{2} \mathrm{O}_{7}$ in $\mathrm{H}_{2} \mathrm{SO}_{4}$ and the subsequent determination of the trivalent chromium equivalent content of organic substances, using a photoelectrocolorimeter (a modification of Tyurin's method) [37].

The empirical data of the soil erosion measurements with close-growing vegetation [38] were processed using a relief function LS (by Renard et al. [39]), which allowed a differentiated consideration of the specific features of the slopes when Slope (S) $<9 \%$ or $\geq 9 \%$ and for Length (L) $<4 \mathrm{~m}$ or $\geq 4 \mathrm{~m}$. To process the data, we used the software product Statistica Advanced $+Q C$ for Windows v.10. 


\subsection{The Climatic Features of the Study Area}

The climatic parameters were taken from the regional reference book [40] on meteorological stations, which characterizes the specific features of individual regions in the first polygon of the study area (Yevpatoria (West), Kerch (East), and Simferopol (South)) and in the second polygon of the study area (Yalta) (Table 2). These data were used for the evaluation of energy expenses on soil formation $(\mathrm{Q})$. When we introduced these to the formula found in Reference [41], converting the radiation balance values to an international system of unit measurement values (conversion of calories into joules), the calculation formula for the value of $\mathrm{Q}\left(\mathrm{MJ} /\left(\mathrm{m}^{2} \cdot\right.\right.$ year $\left.)\right)$ was modified into the following form:

$$
Q=R \cdot e^{\left(-1.23 \frac{R^{0.73}}{P}\right)},
$$

where $\mathrm{R}$ is the radiation balance $\left(\mathrm{MJ} /\left(\mathrm{m}^{2} \cdot\right.\right.$ year $\left.)\right)$ and $\mathrm{P}$ is the annual rainfall $(\mathrm{mm})$.

Table 2. Climate parameters [40] for polygons (I, II) and regions of research.

\begin{tabular}{|c|c|c|c|c|}
\hline Polygons & & I & & II \\
\hline Regions & West & East & South & SCC \\
\hline $\mathrm{T}$ year $\left({ }^{\circ} \mathrm{C}\right)$ & $9.8-11.0$ & $10.4-11.0$ & 10.3 & $10-12$ \\
\hline$\Sigma \mathrm{T}>10^{\circ}$ & $3335-3400$ & $3340-3460$ & 3160 & 3655 \\
\hline Precipitation (mm) & 355 & $225-375$ & 450 & 430 \\
\hline Total evaporation (mm) & 744 & 760 & 855 & 925 \\
\hline $\mathrm{Q},\left(\mathrm{MJ} \mathrm{m}^{-2}\right.$ year $\left.^{-1}\right)$ & 1062 & 1155 & 1195 & 1380 \\
\hline Basic soils & $\begin{array}{c}\text { Calcic Chernozem, } \\
\text { Petrocalcic } \\
\text { Chernozem, } \\
\text { Rendzic Leptosol }\end{array}$ & Luvic Chernozem & Calcic Chernozem & Calcaric Cambisols \\
\hline
\end{tabular}

Note: SCC, the South Coast of Crimea; Q, radiation energy expenses on soil formation [41].

\section{Results}

The estimates of the rate of soil formation and of its most important indicator-the rate of formation of the humus horizon of soils-have been used to solve various scientific and practical problems: for the normalization of erosion losses of soil in the determination of T-values [42,43]; for correcting the necessary efficiency of erosion control measures [44]; for calculating the location of erosion control boundaries in agricultural landscape conditions [45]; for determining the durability of soil use in the presence of anthropogenically caused water and wind erosion [46]; and as an indicator of the regenerative capacity of an ecosystem [47].

\subsection{T-values and the Rate of Soil Formation}

The T-value, before the emergence of empirical and reliable data on the rate of soil formation (1940s-1950s), was determined through the values of geological erosion. Therefore, it makes sense to present erosion estimates from field observations. Estimates of erosion with close-growing vegetation at 12 locations in 10 states of the U.S., with an average amount of annual precipitation between $760-1850 \mathrm{~mm}$ [38], indicated that normal slope erosion was likely $0.22-1.34$ ton per ha annually on land suitable for agriculture. In our work, a deeper analysis of these interesting data was carried out (see Figure 2). Processing the measurement results of erosion losses with close-growing vegetation, according to 307 experiments [38], showed that, in geomorphological conditions in which the slope varied from $1-32^{\circ}$ (at an average of $8^{\circ}$ ), with a length of $21 \mathrm{~m}$, the calculated value of LS (according to Renard et al. [39]) was $1.7(0.25 \div 5.57)$ and the average soil loss value (at runoff values $<120 \mathrm{~mm} ; \mathrm{n}=32$ ) was $0.20 \pm 0.12(0 \div 1.64) \mathrm{t} \mathrm{ha}^{-1}$ year $^{-1}$. Moreover, it was only when the value of the runoff was greater than $122-198 \mathrm{~mm}(\mathrm{n}=4)$ that the average value of soil loss reached $2.6 \mathrm{t} \mathrm{ha}^{-1} \mathrm{year}^{-1}$. Additionally, it is important to note that if soil protection by the vegetation is effective, then, on short slopes, soil-loss dependence on the terrain conditions and the runoff layer was not detected (see Figure 2). 


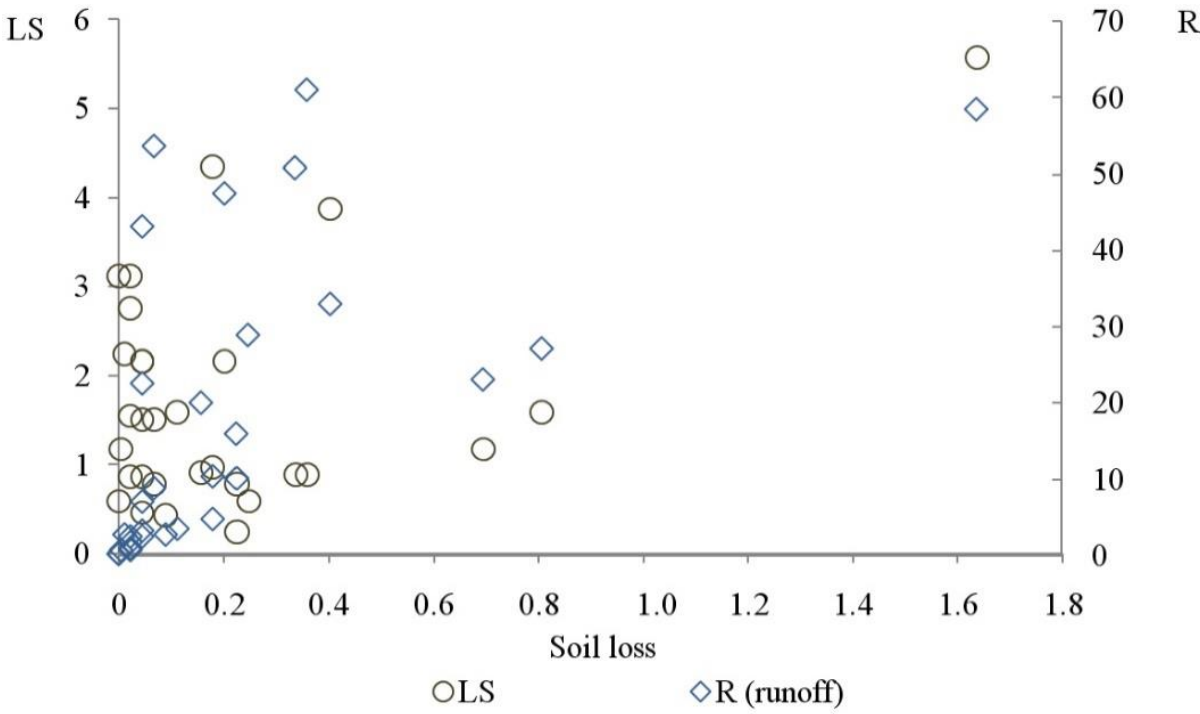

Figure 2. Distribution of the soil loss values $\left(\mathrm{t} \mathrm{ha}^{-1}\right.$ year $\left.{ }^{-1}\right)$, depending on the values of the relief function (LS) and runoff ( $\mathrm{R}, \mathrm{mm})$. Source data from Ref. [38].

In favourable conditions, the rate of soil formation $\left(2.5 \mathrm{~mm}\right.$ year $\left.{ }^{-1}\right)$ is greater than the average rate of denudation ( $1 \mathrm{~mm}$ year ${ }^{-1}$ ); however, anthropogenic erosion (average $2 \mathrm{~mm} \mathrm{year}^{-1}$ ) is significantly greater than natural rates of soil formation $\left(0.02\right.$ to $\left.0.5 \mathrm{~mm}_{\text {year }}{ }^{-1}\right)$ and rates under normal agricultural practice $\left(0.25 \mathrm{~mm}\right.$ year $\left.^{-1}\right)$ [48]. The erosion rates of cultivated agricultural fields with traditional land-use practices are of 1-2 orders of magnitude greater, on average, than the rates of soil production, erosion under native vegetation, and long-term geological erosion [49].

It is important to note that the direct identification of T-values with the rate of soil formation has shown its lack in viability, for a number of reasons: The rate of natural soil formation is often an order of magnitude lower than the desired rates (possible for the organization of anti-erosion monitoring); and agricultural landscape soils are characterized by rates which differ from those in the conditions of natural soil formation. It is noteworthy that the crude evaluation of soil formation " 1 inch in 30 years" [50] served as the only basis for establishing the upper limit of the T-value, which has been used in the soil conservation practices for agriculture in the U.S. [51-53] and which is often applied to other soil-climatic conditions of the world [54-59]. However, since the rate of soil formation depends on time, a stricter substantiation is needed, using large arrays of empirical data. Current approaches for calculating T-values lack a strong scientific basis, and few practicable methods are available $[60,61]$.

\subsection{Summarized Rates of Soil Formation}

A significant sampling of the earliest estimates of natural soil formation is presented in the book Buol, Hole, and McCracken [62], and in the reviews by Buol et al. [62]. The table includes 11 dated soil horizons (profiles) from works published between 1940-1960, where the authors noted their problematic nature. A summary of absolute soil age by Dolgilevich [2] included works from 1866-1970 and presented the estimated rates for pedogenesis of $0.28 \pm 0.06 \mathrm{~mm} \mathrm{year}^{-1}$ (Chernozems) and $0.36 \pm 0.17 \mathrm{~mm}$ year ${ }^{-1}$ (Kashtanozems). These summaries presented a total of 26 individual dates (pedogenesis chronological points). Patterns in the humus formation horizons for the main zonal types of soils of the East-European Plain on rocks of loamy composition were established by generalizing the data in the literature and through regional research (output $n=158$ ) [63]. The mean soil rate, with a bulk density of $1.2 \mathrm{t} \mathrm{m}^{-3}$, fluctuated from $0.2-0.3 \mathrm{t} \mathrm{ha}^{-1}$ (light chestnut and podzolic soils) to $0.5 \mathrm{t} \mathrm{ha}^{-1}$ (typical Chernozems). We carried out a generalization of the data from the literature of the 1970s-1990s (according to 78 estimates), which showed that, under natural conditions of pedogenesis, the average rate of formation of the humus horizon could be estimated as $0.162 \mathrm{~mm}^{-1} \mathrm{yr}^{-1}$, with oscillations of 80 times (from 0.0125 to $1 \mathrm{~mm}^{\text {year }}{ }^{-1}$ ). Similar results were obtained when generalizing the 
average interval estimates in 67 publications: $\Delta \mathrm{H} / \Delta \mathrm{t}=0.132 \pm 0.02 \mathrm{~mm}_{\text {year }}{ }^{-1}\left(0.018 \div 0.85 \mathrm{~mm}_{\text {year }}{ }^{-1}\right)$. The distribution of average interval estimates showed that, most often (in $55 \%$ cases), the average rates of soil formation are estimated by the value of up to $0.2 \mathrm{~mm}_{\text {year }}{ }^{-1}$. Thus, the totality of the data contained in the existing literature forms the notion that the average rate of formation of the humus horizon, under the effect of the natural factors of the pedogenesis at an equilibrium bulk density (we shall assume it to be equal to $\left.1.25 \mathrm{t} \mathrm{m}^{-3}\right)$, is $1.65-2.0 \mathrm{tha}^{-1}$ year ${ }^{-1}$.

The major factors of soil formation (climate, organisms, relief (topography), and parent material) are equally important, but their impact on pedogenesis may change over time, depending on soil age and the stage of soil development [31]. The development of the soil over time, as well as the rate of erosion, is largely dependent on the physical and geochemical characteristics of the soil [64]. Estimates for the rate of soil formation may be obtained through a description of the biogeochemical processes of the transformation of the parent rocks into soils and, in a simpler form, if we consider two related processes: the formation of the thickness of the humus horizon of soils and the accumulation of soil organic carbon (SOC) in it.

We introduce the following notation: $H$ is the thickness of the humus horizon (mm); $H_{\text {s-lim }}$ is the limiting value of the thickness of the humus horizon, $H$, in specific bioclimatic conditions, for a certain granulometric composition of soil-forming rocks $(\mathrm{mm}) ; t$ is the time of soil formation (years); and $\lambda$ is a coefficient which depends on the bioclimatic conditions of soil formation.

The process of soil development over time can be adequately described using the S-shaped curve family; in particular, using the Gompertz function:

$$
H(t)=H_{\text {lim }} \cdot e^{\left(-e^{a+\lambda t}\right)},
$$

where $\mathrm{H}_{\text {lim }}$ is the limiting value of the thickness of the humus horizon which the soil can reach during a development period equal to the period of Holocene ( $\mathrm{mm}$ ); and $a$ and $\lambda$ are empirical factors, where $a$ may be interpreted as the level of the original fertility of the soil-forming rocks and $\lambda$ is the coefficient of the dynamics of the process, over a length of 1 year.

The choice of a Gompertz function seems appropriate for our purposes, as the use of this equation makes it possible to outline the key phases of the growth of the humus horizon.

A substantiation of the empirical coefficients in Equation (2) was carried out for the Chernozem using a large amount of pedochronological material.

The properties of the soil formation model may be better studied when written in a differential form, assuming that all variables change continuously. The replacement (unintentionally, or as a result of a calculation) of a non-linear function with a linear one leads to the fact that the correspondence is reached only at the point of intersection and, before that, the rate estimates are under-estimated; however, afterwards, they are over-estimated. The most accurate representation of the rate of soil formation is the single-moment rate $(V=d H / d t)$. In connection with the non-linear dependence $d H / d t=$ $f(H)$, the averaged rate $\Delta H / \Delta t$ is not equal to the single-moment rate $d H / d t$.

By differentiating Equation (2), a dependency was obtained to determine the rate of soil development over time, which has the form:

$$
V(t)=-H_{\text {lim }} \cdot \lambda \cdot e^{(-a+\lambda t)} \cdot e^{\left(-e^{a+\lambda t}\right)},
$$

Analysis of the Gompertz function gives valuable information on the regularities of pedogenesis. A special feature of this function is the presence of three critical points, denoting the turning moments in the dynamics of the growth processes. Their definition is based on the calculation of the first and second derivative functions (with respect to the rate and to the acceleration of growth). The use of the Gompertz function can be considered as a general solution for a model of pedogenesis and as the best option for approximation for the data of soils with a complex development; as, for example, was shown earlier for forest-steppe soils of the East-European plain [16]. 
The calculation of the soil formation rate for Holocene soils in the study region was carried out using the following parameters: $\lambda=-0.00029$ and $a=0.742$. The estimates of the potential rates characterize the average long-term heat and moisture supply regime that developed during the instrumental observation period.

\subsection{Regional Chronofunctions of Changes of the Humus Horizon}

The degrees of soil degradation in mountainous, foothill, and plain Crimean areas are diverse, requiring differentiated erosion control measures. Therefore, in the mountains (polygon II), the calcaric Cambisols were 70\% eroded, as in many Mediterranean regions (including Greece, where erosion includes about half of the cultivated, hilly, and mountainous areas of the country [65]).

For the territory of the Crimean Plainland (polygon I), the data of the thickness of the horizons A and $\mathrm{AB}$ were generalized earlier [31]. These were used later for mathematical modeling (see Figure 3). Data approximation using a polynomial was used to establish the confidence limits. It should be noted that, within the confidence intervals (which reflect the intra-regional differences), it is possible to outline a family of curves which will be governed by the same regularity, as established by the exponential (Jenny [66]) and S-type equations. In particular, a comparison of the calculated values for these models with the use of the Kolmogorov-Smirnov test [67] showed that the models for the studied soils gave results for which the difference was insignificant $(\mathrm{P}=0.95)$.

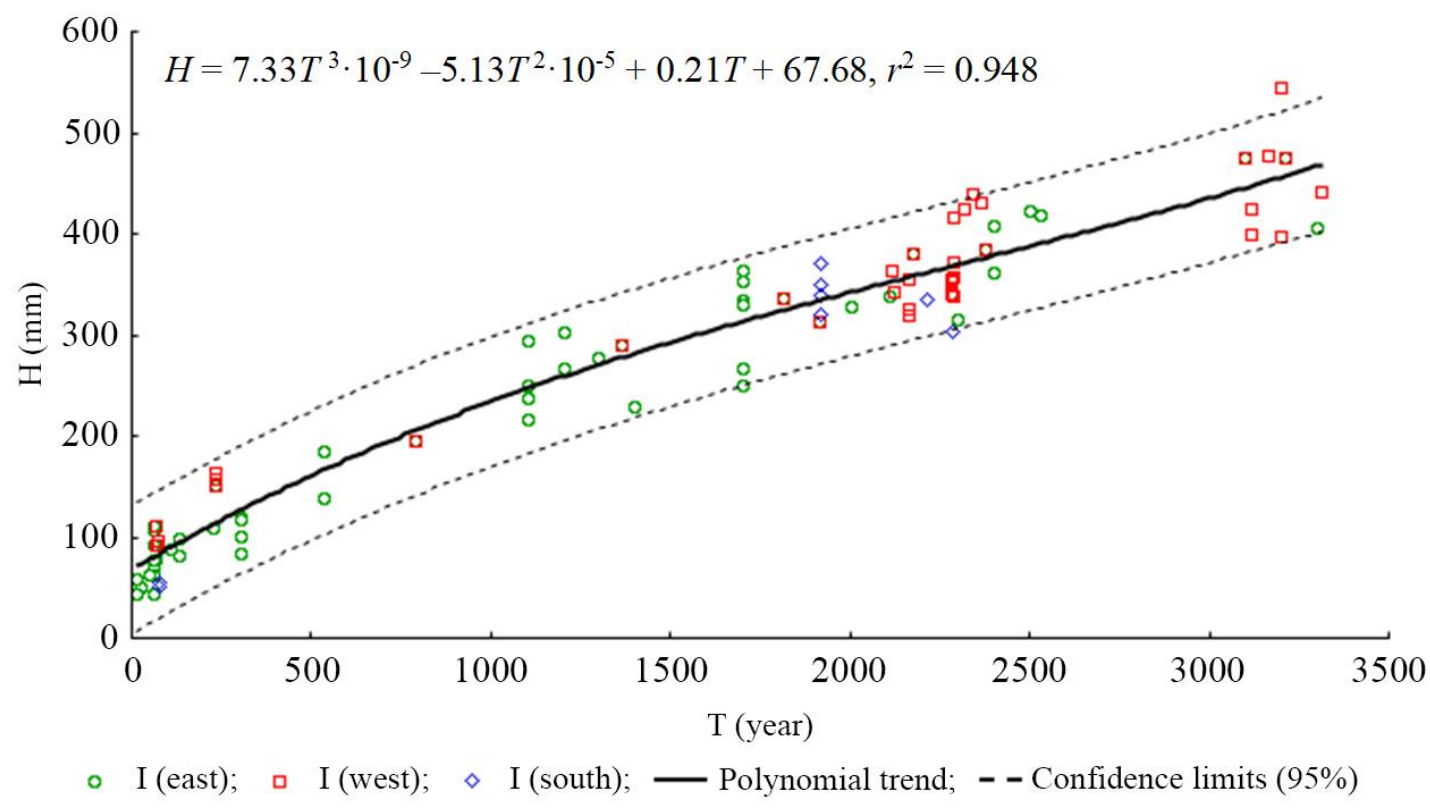

Figure 3. Chronofunctions of changes of the humus horizon $(\mathrm{H}, \mathrm{mm})$ for the soils of polygon (I)-type (see Table 2$)$ over time $(\mathrm{T}$, year). Confidence limits $(\mathrm{P}=0.95)$.

For the function of the 3500-year changes in the thickness of the humus horizon of the Chernozems (with $\mathrm{H}_{\mathrm{lim}}=800 \mathrm{~mm}$ ), according to the model of exponential type, the following empirical coefficients were determined: $\mathrm{a}=0.785$ and $\lambda=0.000466$. The maximum growth rate of the Crimean Chernozems was observed in the first few decades of soil formation, reaching 2-4 $\mathrm{mm} \mathrm{year}^{-1}$ [31]. During the subsequent phase (by 1600-1800 AD), the soil reached maturity, after which the soil formation rates irreversibly slowed down, if the soil-forming potential of the environment did not change. Land withdrawn from agricultural use (for example, as done in the U.S., according to the Conservation Reserve Program (CRP)) has implications for evaluating the effects on amount and rate of soil organic carbon (SOC) storage and retention, and maintenance and restoration of soil productivity of previously-eroded soils [68]. An increase of biodiversity stimulates soil formation: complex poly-dominant communities ensure stable and quick soil reproduction (up to $4 \mathrm{~mm} \mathrm{year}^{-1}$ ) [69]. At the 
initial stages of pedogenesis, when the highest renewal rates are observed, there occurs a replacement "ecosystem attractor", which controls the process of accumulation of SOC, in situ, in the layer of maximum development of the parent rock by the biota, a "climatic attractor" [70]. For Chernozems, this replacement occurs after 70-170 years, when the soil reaches the first 15-20 cm of thickness of the humus horizon [71].

Field studies in 2016 permitted us to obtain new results, by studying calcaric Cambisols at archaeological sites for the SCC territory with sub-Mediterranean conditions (Table 3).

Table 3. Parameters of soil chronosequences at archaeological sites of the SCC with sub-Mediterranean conditions.

\begin{tabular}{|c|c|c|c|c|c|c|c|c|c|}
\hline $\begin{array}{l}\text { Archaeological } \\
\text { Site }^{\text {a }}\end{array}$ & $\begin{array}{c}\text { Soil Age } \\
\text { (years) }\end{array}$ & $\begin{array}{c}\text { Parent } \\
\text { Material }^{\text {a }}\end{array}$ & $\begin{array}{c}\text { Horizon, } \\
\text { Levels }(\mathrm{mm})\end{array}$ & $\begin{array}{c}\text { Munsell } \\
\text { Colour (dry) }\end{array}$ & $\begin{array}{c}\mathrm{CaCO}_{3} \\
(\%)\end{array}$ & $\begin{array}{c}\mathbf{p H} \\
\mathrm{H}_{2} \mathrm{O}\end{array}$ & $\begin{array}{l}\text { Corg } \\
(\%)\end{array}$ & $\begin{array}{c}\Delta C(\% \\
\left.\text { year }^{-1}\right), n \cdot 10\end{array}$ & $\begin{array}{c}\Delta \mathrm{H} \\
\left(\mathrm{mm}^{2} \text { year }^{-1}\right)\end{array}$ \\
\hline Kutlak & 25 & $\mathrm{~L}$ & AC, $0-29$ & 10YR 5/3.5 & 4.6 & 7.9 & 3.96 & 1.58 & 1.17 \\
\hline Kharaks & 30 & $\mathrm{CaG}$ & $\mathrm{AC}, 0-77$ & 10YR 5/3 & 26.2 & 8.2 & 13.86 & 3.75 & 2.57 \\
\hline Ayu-Dag & 42 & $\mathrm{~L}$ & AC, $0-25$ & 10YR 5/3.5 & - & 7.3 & 3.48 & 0.83 & 0.60 \\
\hline \multirow{2}{*}{ Bol'shoi Lambat } & \multirow{2}{*}{87} & \multirow{2}{*}{$\mathrm{CaG}$} & AC, $0-50$ & 10YR 4/2 & 14.4 & 6.8 & 7.13 & 0.82 & \multirow{2}{*}{0.84} \\
\hline & & & $\begin{array}{c}\text { AC, } 50-73 \\
\text { AC, } 0-30\end{array}$ & $\begin{array}{c}10 Y R 4 / 2.5 \\
10 Y R \text { 5/3 }\end{array}$ & $\begin{array}{c}14.8 \\
2.5\end{array}$ & $\begin{array}{l}7.5 \\
7.2\end{array}$ & $\begin{array}{l}5.87 \\
4.11\end{array}$ & $\begin{array}{l}0.67 \\
0.41\end{array}$ & \\
\hline Ayu-Dag & 100 & $\mathrm{~L}$ & AC, $30-50$ & 10 YR $5 / 3.5$ & 2.2 & 7.4 & 3.16 & 0.32 & 0.51 \\
\hline \multirow{2}{*}{ Kharakskii park } & \multirow{2}{*}{107} & \multirow{2}{*}{$\mathrm{CaG}$} & $\mathrm{AC}, 0-40$ & $10 Y R 5 / 3$ & 22.5 & 8.4 & 14.74 & 1.58 & \multirow{2}{*}{0.79} \\
\hline & & & AC, $40-85$ & 10YR 5/5 & 3.8 & 8.7 & 2.87 & 0.31 & \\
\hline \multirow{3}{*}{ Ayu-Dag } & \multirow{2}{*}{316} & \multirow[b]{2}{*}{$\mathrm{L}$} & $\mathrm{AC}, 0-66$ & 10YR 5/4 & 3.4 & 6.3 & 6.35 & 0.18 & \multirow{2}{*}{0.41} \\
\hline & & & AC, $66-145$ & 10YR 6/3 & 2.5 & 6.1 & 5.51 & 0.16 & \\
\hline & 316 & $\mathrm{CaG}$ & $\mathrm{AC}, 0-83$ & 10YR 6/2.5 & 1.5 & 4.8 & 6.93 & 0.25 & 0.30 \\
\hline \multirow{2}{*}{ Bol'shoi Lambat } & \multirow{2}{*}{560} & \multirow{2}{*}{ WC } & $\mathrm{AU}, 0-64$ & 10YR $4 / 2$ & 2.8 & 5.9 & 2.35 & 0.04 & \multirow{2}{*}{0.33} \\
\hline & & & BCA, 64-185 & $10 \mathrm{YR} 4 / 2.5$ & 1.8 & 5.6 & 5.86 & 0.10 & \\
\hline \multirow{2}{*}{$\begin{array}{c}\text { Isar Gelin-Kaya } \\
\text { (Kizil-Tash) }\end{array}$} & \multirow[b]{2}{*}{610} & \multirow[b]{2}{*}{$\mathrm{CaG}$} & AU, $0-188$ & $10 \mathrm{YR} 4 / 2$ & 17.5 & 8.1 & 7.57 & 0.12 & \multirow[b]{2}{*}{0.44} \\
\hline & & & B, $0-270$ & $10 Y R 5 / 3$ & 26.6 & 8.3 & 14.36 & 0.24 & \\
\hline & \multirow[b]{2}{*}{700} & \multirow[b]{2}{*}{ WC } & $\mathrm{AU}, 0-60$ & $10 \mathrm{YR} 3 / 3$ & 6.8 & 8.0 & 3.39 & 0.05 & \\
\hline & & & $\mathrm{AU}, 60-182$ & $10 \mathrm{YR} 4 / 3$ & 6.8 & 8.0 & 7.27 & 0.10 & 0.26 \\
\hline Uchan-Su-Isar & & & AU, $0-135$ & $10 \mathrm{YR} 3 / 3$ & 6.5 & 7.9 & 3.11 & 0.04 & \\
\hline & 700 & WC & B, 135-196 & 10YR $4 / 3$ & 6.8 & 7.9 & 7.38 & 0.11 & 0.28 \\
\hline & & & $\mathrm{AU}, 0-46$ & 10YR $4 / 2$ & 4.0 & 7.2 & 6.58 & 0.12 & \\
\hline Bol'shoi Lambat & 700 & $\mathrm{CaG}$ & AU, 46-103 & $10 \mathrm{YR} 4 / 2$ & 4.6 & 7.6 & 4.35 & 0.08 & 0.18 \\
\hline Alupka-Isar & & & AU, $0-160$ & $10 \mathrm{YR} 4 / 2$ & 3.8 & 8.3 & 3.12 & 0.04 & \\
\hline Alupka-Isar & 710 & $\mathrm{CaG}$ & B, $160-229$ & 10YR 6/2 & 12.0 & 8.3 & 8.12 & 0.11 & 0.32 \\
\hline & & & AU, 0-124 & $10 \mathrm{YR} 3 / 2$ & 10.4 & 7.2 & 7.86 & 0.11 & 7ר? \\
\hline Oreanda-Isar & 717 & $\mathrm{CaG}$ & AU, $124-190$ & $10 \mathrm{YR} 4 / 3$ & 18.8 & 8.2 & 4.94 & 0.07 & 0.27 \\
\hline Oreanda-Isar & 717 & WC & AU, $0-180$ & $10 \mathrm{YR} 4 / 2.5$ & 19.1 & 8.0 & 3.90 & 0.05 & 0.25 \\
\hline & & & $\mathrm{AU}, 0-130$ & 5YR 3/2 & 4.2 & 7.8 & 2.29 & 0.01 & \\
\hline Kharaks & 1700 & WC & B, $130-183$ & $5 Y R 3 / 4$ & 2.5 & 8.2 & 2.09 & 0.01 & 0.11 \\
\hline & & & AU, $0-152$ & 10YR $5 / 3$ & 23.6 & 8.2 & 11.51 & 0.07 & \\
\hline Kharaks & 1700 & $\mathrm{CaG}$ & AU, 152-260 & 10YR 5/4 & 24.4 & 8.2 & 14.38 & 0.08 & 0.15 \\
\hline & & & B, $260-320$ & 10YR 6/3 & 26.2 & 8.4 & 13.97 & 0.08 & \\
\hline & & & AU, 0-25 & 10YR 4/1 & 3.7 & 6.3 & 8.64 & 0.05 & \\
\hline Bol'shoi Lambat & 1920 & $\mathrm{~L}+[\mathrm{A}]$ & $\mathrm{AU}, 25-120$ & 10YR 5/1.5 & 2.8 & 7.0 & 4.56 & 0.02 & 0.13 \\
\hline & & & B, $120-254$ & 10YR 5/1.5 & 3.1 & 7.5 & 2.20 & 0.01 & \\
\hline Protected soil & & & AU, 0-60 & 5YR 3/1.5 & 4.8 & 8.0 & 4.35 & 0.004 & - \\
\hline (Cape Martjan) & $>10000$ & $\mathrm{CaG}$ & AU, $60-200$ & 5YR $4 / 4$ & 2.5 & 7.4 & 2.03 & 0.002 & \\
\hline
\end{tabular}

Note: ${ }^{\text {a } W C}$, weathering crust; CaG, clay and gravel; L, loam.

During pedogenesis, according to the equation of change in the thickness of the humus horizon $(A+B)$ of calcaric Cambisols over time (see Figure 4), between the ages 100 and 2000, the total thickness A+B increased from 60 to $260 \mathrm{~mm}$. However, the ratio A/B remained practically unchanged over time: $\bar{x} \pm t_{0.5} \cdot S_{\bar{x}}=1.15 \pm 0.12(1.03 \div 1.27)(\mathrm{n}=20)$. 


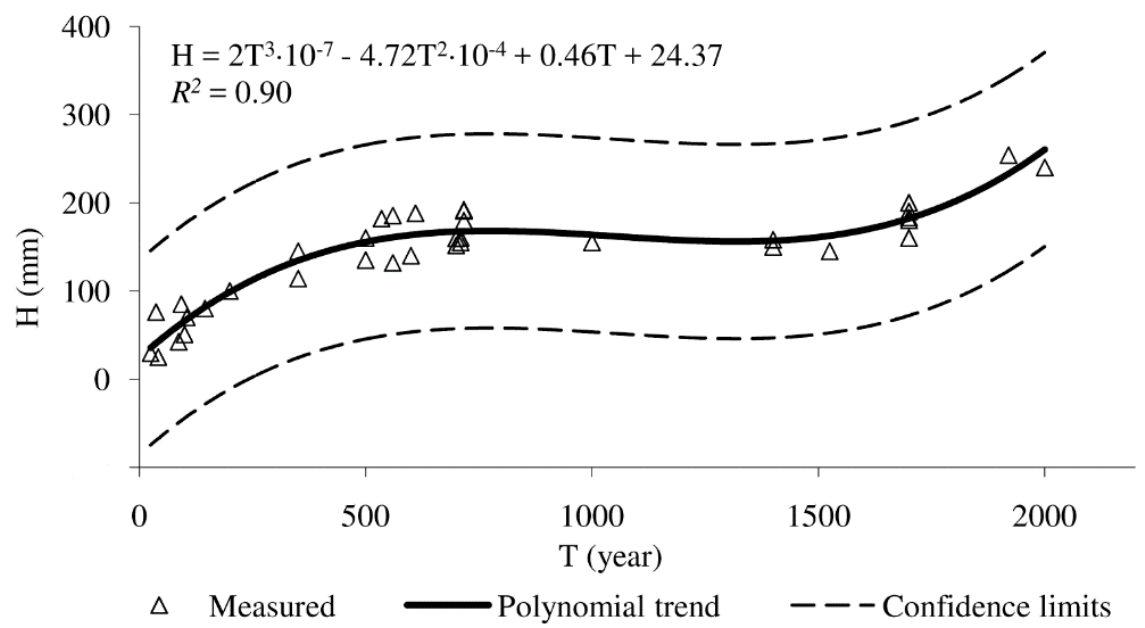

Figure 4. Chronofunctions of changes of the humus horizon $(\mathrm{H}, \mathrm{mm})$ of the calcaric Cambisols over time $(\mathrm{T}$, years). Confidence limits $(\mathrm{P}=0.95)$.

The data in Table 3 (average values $\Delta \mathrm{H}$ ) show that the calcaric Cambisols in the region with sub-Mediterranean conditions formed humus horizons over the last 2000 years with an average rate of $\Delta \mathrm{H}=0.52 \pm 0.13 \mathrm{~mm}_{\text {year }}{ }^{-1}$. The average annual rate of formation of the humus horizon of the soil chronosequence decreased with time, from 2 to $0.12 \mathrm{~mm}_{\text {year }}{ }^{-1}$ (Table 3). Over time, the growth rates of the humus horizon thickness decreased: up to 100 years, $\mathrm{dH} / \mathrm{dt}=6.8 \mathrm{~mm} 100$ year $^{-1}$; from

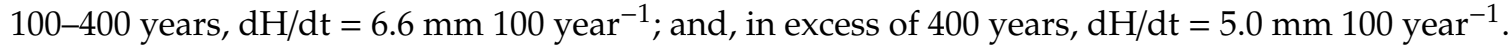

Despite the predominance of dense carbonate rocks as the parent rock (with the content of $\mathrm{CaCO}_{3}$ being $9.56 \pm 1.42 \%$ ), the pedogenesis was due to favourable climatic conditions: very mild winters where a major amount of precipitation falls, and there is a high degree of heat supply. This was also the cause of the accelerated accumulation of soil organic carbon: $\Delta C(n \cdot 10)$ formed at $0.27 \pm 0.13 \%$ year $^{-1}$. As shown earlier [35,72], in the chronological series of the calcaric Cambisols, the humus content in the upper horizon increases with age, from $4.1 \%$ to $7.0-9.6 \%$. A significant humus accumulation was observed in soils aged at only several centuries (Table 3). Subsequently, the rate of humus accumulation decreased. During the Holocene, soil evolution in the cinnamonic soils zone of southwestern Crimea was marked by active humus accumulation (about $0.04 \% / 100$ year), as well as an enrichment in nitrogen of the humus [72]. According to Table 3, the rates of the processes of accumulation of organic carbon $\left(\Delta \mathrm{C}, \%\right.$ year $\left.^{-1}\right)$ and the formation of horizon A were generally synchronous, up to periods of 2000 years, with the exception of the first 100 years, where the humus accumulation (with a decrease in the average annual immobilization rate of Corg from $3.75 \%$ to $0.63 \%$ year $^{-1}$ ) outran the process of the deepening of humus substances into the profile.

\section{Discussion}

\subsection{Stages of Engineering and Geographical Arrangement of the Agricultural Landscape}

The engineering and landscape substantiation of geo-planning (landscaping and land use) allows us to outline the following main stages of the arrangement of agricultural landscapes, which are capable of ensuring soil conservation and ecological purposes.

1. The use of Geographic Information Systems, in particular GIS mapping of the agricultural landscape territorial structures. In addition to reflecting the landscape morphology, natural-economic systems, and infrastructural elements of economic and natural conservation activities, taking into account the positional (catenary) junctions of the landscape is important for slope farming.

2. Three-dimensional parametrization of the structure (based on a digital model of the relief and terrain model) and evaluation of the performance indicators of agricultural landscape systems. Of particular importance are estimates of the resource potential, as well as resource forming and 
degradation processes. To optimize land use, it is promising to use integrated estimation indicators, including estimates of the rates of destruction, reproduction, and quality of the soil (see approach 3 in Table 1).

3. The engineering and landscape justification of the location of the linear elements of soil conservation systems and of watersheds, as well as selection of the type (construction) of flow regulation and water disposal systems. The optimal use strategy is chosen by means of iterative calculations.

4. Use of methods for evaluating the delivery of sediments from watershed slopes into permanent watercourses [73].

5. Formation of an ecologically-balanced landscape structure (an optimal ratio of arable land, forest, meadow, and water). The current state of use may be quickly evaluated using high-resolution images from Google Earth [74], or from other similar services. However, the task is to use these results for an environmentally friendly and resource-saving landscape, for lean and responsible land use.

6. Identification of the landscape for natural-reserve and historical-cultural purposes. Planting of camouflaging, dust, and noise-control vegetation. Development of architectural and planning solutions for improving the aesthetics of the agricultural landscape.

7. Formation of a structure for agroecological monitoring, functionally connected with the regional GIS.

Two basic approaches for optimizing the use of soil resources in erosion-hazard areas have been determined [6] on the basis of commonly used criteria (resource, ecological, economic) for optimizing and simulating. However, taking into account the multi-criteria nature of the problem of optimization and the non-linearity of the algorithms that describe the behaviour of erosion systems in agricultural landscapes, strictly practical implementation of this task using formal mathematical optimization methods is impossible. Therefore, almost the only approach in the optimization of land use in erosion-hazard areas remains to be multi-variate simulation modeling.

A practical implementation of the methods for optimizing the use of erosion-hazard landscapes requires the involvement of advanced information technologies. Moreover, in view of the fact that the task of multi-criteria optimization of land use cannot be fully formalized, the best option for the use of land resources (i.e., that is optimal in terms of the totality of the economic, environmental, and social criteria) will be provided by the method of simulation with a subsequent analysis and assessment of the results [6]. Most effectively, this problem may be solved using computerized decision support systems, which, in addition to software-based mathematical models of basic processes, optimization criteria, and decision-making algorithms, include a data bank, a scenario library, and an interface module providing communications between the computer system and the user or a group of professionals.

\subsection{The Determine of T-values for Agricultural Landscapes}

It is clear that the estimates for the rate of formation of the humus horizon should receive a more thorough empirical substantiation, both in terms of the conditions for natural pedogenesis and taking into account the direct and indirect effects of economic factors on agricultural landscapes.

The phytomass production, which is provided by broad-leaved forests in the forest-steppe, constitutes 11-12.7 tha ${ }^{-1}$, and meadow steppes annually produce $19.9 \mathrm{t} \mathrm{ha}^{-1}$ of phytomass, including a $65 \%$ share of the underground production [75]. In the conditions of natural steppe ecosystems, $4 \mathrm{t}$ $\mathrm{ha}^{-1}$ of roots are involved in the complete cycle of transformation in the humus-accumulative horizon of the soil every year, which ensures the annual input of $0.87 \mathrm{t} \mathrm{ha}^{-1}$ humus, 3.5 times higher than its input due to surface littering in steppes under fescue, and 1.6 times higher if feather-grass dominates in the steppe. The calculated value for the total renewal of the humus in the layer between $0-20 \mathrm{~cm}$ in steppe soils is 110 years [75].

It is advisable to adjust the possible degree of achieving the potential rate of soil formation in specific agricultural landscape conditions with a process loop by using a model that reflects the rates of anthropogenic soil formation (taking into account the soil quality (SQ) and its changes because of erosion and reproduction of organic matter). 
In general, the balance equation of the process of humus formation, which reflects the change in the components of the balance over one year, may be written as follows:

$$
\Delta \overline{\mathrm{C}}_{a}+\Delta \overline{\mathrm{C}}_{b}+\Delta \overline{\mathrm{C}}_{c}+\Delta \overline{\mathrm{C}}_{d}+\Delta \overline{\mathrm{C}}_{q}+\Delta \overline{\mathrm{C}}_{p z}+\Delta \overline{\mathrm{C}}_{n s}+\Delta \overline{\mathrm{C}}_{m}+\Delta \overline{\mathrm{C}}_{s}=\Delta \overline{\mathrm{C}}_{p}+\Delta \overline{\mathrm{C}}_{m n}+\Delta \overline{\mathrm{C}}_{i z}+\Delta \overline{\mathrm{C}}_{e}+\Delta \overline{\mathrm{C}}_{z}+\Delta \overline{\mathrm{C}}_{g} \pm \Delta \overline{\mathrm{C}}
$$

where the input of humus $\left(\mathrm{t} \mathrm{ha}^{-1}\right)$ is provided by the following sources: the remains of agricultural crops $\left(\Delta \bar{C}_{a}\right)$ and weeds $\left(\Delta \bar{C}_{b}\right)$; organic fertilizers $\left(\Delta \bar{C}_{d}\right)$; consolidation in organo-mineral compounds during soil formation $\left(\Delta \bar{C}_{s}\right)$; and the nitrogen balance input $\left(\mathrm{kg} \mathrm{ha}^{-1}\right)$ items, converted using the coefficient 0.02 ( 1 ton of humus contains, on average, $50 \mathrm{~kg} \mathrm{~N}$ ) into an adequate amount of humus (in units $\mathrm{t} \mathrm{ha}^{-1}$ ): input from the seed material $\left(\Delta \bar{C}_{c}\right)$; from nitrogen and complex fertilizers $\left(\Delta \bar{C}_{q}\right)$; from atmospheric precipitation $\left(\Delta \bar{C}_{p z}\right)$; from symbiotic consolidation by leguminous crops, herbs, and lifetime root secretions $\left(\Delta \bar{C}_{n s}\right)$; and due to fixation of atmospheric nitrogen by soil micro-organisms $\left(\Delta \bar{C}_{m}\right)$.

The expenditure of humus is related to the following items: erosion $\left(\Delta \bar{C}_{e}\right)$; renewal of humus resources and its mineralization during mechanical soil cultivation $\left(\Delta \bar{C}_{m n}\right)$; profile migration in humid areas and irrigation of soils $\left(\Delta \bar{C}_{i z}\right)$; and expenditure items for the nitrogen balance: biological removal by crops and weeds $\left(\Delta \bar{C}_{p}\right)$, removal of mineral fertilizers as a result of runoff $\left(\Delta \bar{C}_{z}\right)$, and losses in the form of gaseous compounds $\left(\Delta \bar{C}_{g}\right)$.

The input component of the process of humus formation $\left(\Delta C_{a r}\right)$ is mainly composed of the plant (surface and root) residues of agricultural crops, organic fertilizers, and (indirectly) mineral fertilizers. It may be presented in the form of the following components:

$$
\Delta C_{a r}=\varphi_{g} \cdot K^{\prime}{ }_{h} \cdot A+K^{\prime \prime}{ }_{h} \cdot D+0.02 \cdot \lambda \cdot O_{z} \cdot K_{n}+0.2 \cdot \mu \cdot P,
$$

where $\mathrm{A}$ and $\mathrm{D}$ are the amounts of plant residues and organic fertilizers $\left(\mathrm{t} \mathrm{ha} \mathrm{a}^{-1}\right)$, respectively; $K^{\prime}{ }_{h}$ and $K^{\prime \prime}{ }_{h}$ are their humification coefficients; $O_{z}$ is the dose of (nitrogen or complex) fertilizers of a certain type $\left(\mathrm{kg} \mathrm{ha}^{-1}\right) ; \mathrm{P}$ is the seeding rate $\left(\mathrm{t} \mathrm{ha}^{-1}\right) ; \varphi_{\mathrm{g}}$ is the coefficient of transition from the value of newly formed humus in the arable horizon to the total value of humus formation in the profile; $\lambda$ is the coefficient reflecting the nitrogen content in certain types of mineral fertilizers (varies from 0.04 in ammophosphate to 0.82 in liquid ammonia); $K_{n}$ is the factor of nitrogen usage from mineral fertilizers; and $\mu$ is the nitrogen content in the seed material (\%; the average for cereals is $1.6 \%)$.

$K_{n}$ for arable lands, it is advisable to normalize the T-values by means of an equation where the rate of pedogenesis is associated with the basic changes of soil organic carbon:

$$
T-\text { values }=\frac{H\left(\Delta C_{a r}-\Delta C_{m n}-\Delta C_{g}\right)+C \cdot V}{k \gamma H \cdot C_{P}+C_{0-10}},
$$

where $H$ is the thickness of the humus horizon (mm); $\Delta \mathrm{C}_{\mathrm{ar}}$ is the input component of the process of humus formation due to plant residues and fertilizers $\left(\mathrm{t} \mathrm{ha}^{-1}\right) ; \Delta \bar{C}_{m n}$ is the mineralization of humus, which depends on the structure of crop rotation and yield level $\left(\mathrm{t} \mathrm{ha}^{-1}\right) ; \Delta \overline{\mathrm{C}}_{g}$ is the mineralization (renewal) of passive humus ( $\mathrm{t} \mathrm{ha}^{-1}$ ); $\mathrm{Cp}$ is the humus content in the washable soil layer (\%); $C$ and $C_{0-10}$ are the humus reserves in the humus horizon and the washable soil layer, respectively $\left(\mathrm{t} \mathrm{ha}^{-1}\right) ; \mathrm{V}$ is the rate of soil formation ( $\left.\mathrm{mm} \mathrm{year}^{-1}\right) ; \gamma$ is the bulk density in the washable soil layer $\left(\mathrm{t} \mathrm{m}^{-3}\right)$; and $\mathrm{k}$ is the coefficient of excess of humus content in the solid sink, with respect to the original value.

This solution is less accurate than (Equations (4) and (5)) but is suitable for practical use in SQ management on agricultural lands. Thus, estimates of the rate of soil formation $\left(V, \mathrm{~mm}\right.$ year $\left.^{-1}\right)$, as calculated using pedochronological data and shown in Table 3, are only one of the parameters in justifying the T-values for the modern conditions of agricultural ecosystems. The use of the predicted 
rate of soil loss $(\mathrm{W})$, according to known formulas $[76,77]$ and T-values, makes it possible to obtain a formula for establishing the permissible width $(\mathrm{L}, \mathrm{m})$ of contour strips for slope farming:

$$
L=\left\{\frac{10 \gamma T-W}{1.53 \cdot 10^{-3} j_{R} j_{E} \cdot e^{-\lambda(0.85-100 m)} \cdot K_{g m} S^{n}}\right\}^{2},
$$

where $\mathrm{T}$ is the soil loss tolerance $\left(\mathrm{mm}^{-}\right.$year $\left.^{-1}\right) ; \mathrm{W}$ is the rate of soil loss $\left(\mathrm{t} \mathrm{ha}^{-1}\right.$ year $\left.^{-1}\right) ; \gamma$ is the bulk density in the washable soil layer $\left(\mathrm{t} \mathrm{m}^{-3}\right) ; \mathrm{j}_{\mathrm{R}}$ and $\mathrm{j}_{\mathrm{E}}$ are indicators of relative flushing for individual soils and the extent of their erosion, respectively; $\mathrm{S}$ is the slope (\%); $\mathrm{n}$ is an exponent that depends on the crop and the degree of soil erosion; Kgm is the hydrometeorological parameter of soil wash-out; and $\mathrm{e}^{-\lambda(0.85-100 \mathrm{~m})}$ is a function that reflects the effect of vegetation on soil wash-out [76].

The higher the hazard of the development of erosion processes on a slope is, the narrower the contour strips are (i.e., a smaller value of L, according to Equation (7)), the boundaries between which may be strengthened with banks, ditches, forest belts, and so on.

The natural soil formation rate, which was able to compensate for normal (geological) erosion, was estimated, by the authors, for an area near the Black Sea region, according to the model of surface soil runoff during the summer-autumn period, taking into account soil areas of individual erosion levels. The results showed that the magnitude of the storm water wash-out in this area (with precipitation $400-550 \mathrm{~mm}_{\text {year }}{ }^{-1}$ ) was comparable, in pre-agrarian periods, to the rate of natural pedogenesis, and may be interpreted as the magnitude of normal erosion $\left(0.6 \mathrm{tha}^{-1}\right.$ year $\left.^{-1}\right)$.

Thus, in our opinion, the most promising approach to the problem of normalizing soil erosion losses in agricultural landscapes involves solving two problems. Firstly, instead of the currently accepted average estimates of the rate of soil formation, it is necessary to develop models that reflect the dependence of the rate of soil formation under natural conditions (with a sufficient input of the plant matter) on the morphological and functional maturity of the soil. Secondly, it is advisable to adjust the possible degree of achieving the potential rate of soil formation in specific agricultural landscape and process loop conditions, using a model that reflects the intensity of the anthropogenic soil formation (taking into account the quality of the soil and its changes because of erosion and the reproduction of organic carbon). Agriculture must also address tremendous environmental concerns, as it is now a dominant force behind many environmental threats, including the degradation of land [78]. Implementation of soil biological functions in the standard paradigm of agricultural technology is problematic - the modeling and normalization of the soil should not be done in the customary imitative manner of agricultural technology and land reclamation. Finding new possibilities with acceptable probabilities for the control of new soil evolution quality is on the agenda [79].

\subsection{Use of Pedochronological Data for Land Restoration and Soil Quality}

The state of a soil system may be described either by input-output signals (factors of soil formation and soil properties), or by macro-parameters of the system (such as rate and acceleration) [31]. The rates of formation of the humus horizon $(\mathrm{dH})$ and the accumulation of Corg $(\mathrm{dCorg})$ for the conditions of natural soil formation can provide data on soil chronosequences at archaeological sites, as we did in a particular region (Table 3). Programs for the restoration of degraded lands may effectively use the high initial renewal rates, which are subject to a large input of organic matter into the soil, as in natural ecosystems. The averaged estimates of the soil formation rate, as more and more long stages of the formation of the soil profile are taken into account, will reflect the formed soil to a decreasing degree. The longer the time interval used for calculating the rates, the more the true value of the rate $d H / d t$ will be distorted, due to the differences in the curvilinear dependence $H=f(t)$ on the linear average $\Delta H / \Delta t$ $=H_{2}-H_{1} /\left(t_{2}-t_{1}\right)$.

If the conditions for reproduction of Corg are created in the soils, the rate of soil formation may vary significantly, depending on the residual thickness of the humus horizon (and on the degree of erosive degradation of the soil) (Table 4). 
Table 4. The averaged potential estimates of the rate of formation of the humus horizon $\left(\mathrm{tha}^{-1} \mathrm{year}^{-1}\right)$, depending on the degree of soil erosion degradation.

\begin{tabular}{ccc}
\hline Degree of Erosion Degradation & Chernozems & Cambisols \\
\hline Low & 1.26 & 1.86 \\
Average & 2.03 & 1.47 \\
Strong & 4.50 & 4.69 \\
\hline Equilibrium bulk density is $1.25 \mathrm{t} \mathrm{m}^{-3}$. \\
\hline
\end{tabular}

Note that there are differences, up to 2.5-3.5 times, in the rate of formation of the humus horizon, due to the non-linear nature of changes in the soil-forming process over time, at the initial and final stages of the formation of the soil profile. The estimates of the soil formation rate can be used in the implementation of programs for the ecological rehabilitation of degraded land in the chernozem zone, as well as in the sub-Mediterranean conditions, where the background soils are Cambisols. An indispensable condition, in order to achieve optimal rates of formation of the humus horizon, is implementing effective programs of environmental re-naturation (the use of multi-component grass mixtures, adapted composition of forest cultures, and so on).

However, for arable lands, amendments should be introduced, primarily related to the shortage of plant matter that enters the soil. It was found [80] that the typical black soils (Chernozem), which formed under meadow steppes, contain $2-7 \%$ humus, and the total humus reserves in the meter layer change from 200-650 $\mathrm{t} \mathrm{ha}^{-1}$. When the phytomass production is correlated with the humus reserves, we obtain a ratio which indicates how much of the plant matter ensures the reproduction and deposition of $1 \mathrm{t}$. In a meadow cenosis, an annual organic matter input of $47 \mathrm{~kg}$ per $\mathrm{t}$ of humus ensured the intensity of the natural pedogenesis and the humus formation that characterizes typical black soils (Chernozems). In agricultural cenoses, this indicator is four times lower; if we assume the value of the annual input of organic matter to be from straw and root residues of cultivated plants (without the introduction of organic fertilizers), it is $5 \mathrm{tha}^{-1}$ lower. Thus, under the usual conditions of the advanced economic management of agricultural land, it is difficult to assume that the rates of anthropogenic soil formation may be higher than the rates of the natural process.

For example, for a region near the Black Sea with an advanced structure of field crop rotations (tilled crops, in particular, covered $34 \%$ of the arable land), the magnitude of accelerated erosion was $8 \mathrm{t} \mathrm{ha}^{-1}$ year ${ }^{-1}$ and, thus, the rate of erosion destruction of land after agricultural development started became 14 times higher [62]. Additionally, the quality of the soil resources over the period of advanced agricultural use has changed: the reserves of SOC, due to physical and chemical degradation, lowered by $20-40 \%$ in the arable horizon [81]. The contradictory character of the process of soil formation during agrogenic evolution determines the special importance of representing the changes in both the thickness of the humus horizon $(\mathrm{H})$ and the Corg content in a generalized index. For this purpose, an equation is proposed, which reflects a differentiated contribution into the assessment of the soil quality (SQ) of the most important components (the thickness of the humus horizon and the carbon content):

$$
\frac{d S Q}{d t}=k H^{k-1} \cdot \operatorname{Corg}^{m} \frac{d H}{d t}+m \cdot H^{k} \cdot \operatorname{Corg}^{m-1} \cdot \frac{d \operatorname{Corg}}{d t},
$$

where $\mathrm{k}$ and $\mathrm{m}$ are the exponents for $H$ and Corg, respectively.

The differentiated contribution of the individual components to the assessment of the total soil resource change is reflected by the values of the coefficients $\mathrm{k}$ and $\mathrm{m}$ (for Chernozems, 0.29 and 0.74 , respectively).

The ecological aspects of the connection between soil quality and crop quality are also associated with both the natural features of soil formation and anthropogenic impacts. An important aspect of the assessment of the rate of soil formation is the geochemical composition of the parent rock [82]. The problem of soil contamination with heavy metals arises, even when using conventional mineral fertilizers [83]. 


\section{Conclusions}

This study has shown that an adaptive landscape approach to the geo-planning of ecologically sustainable agricultural landscapes should combine the results of geographic studies of their topography and of functional engineering solutions for obtaining the estimates of potential erosion losses and soil formation. Substantiation of an anti-erosion organization of agricultural landscapes requires not only differentiated estimations of erosion losses (within the watershed, slope, and even points of space), but also commensurate estimations of the soil loss tolerance. Through a critical analysis of the previously developed approaches, this study allowed incorporation of the results of pedogenesis modeling into a computational method for the organization of agricultural landscapes. The results of a study of the process of formation of the humus horizon and of the accumulation of organic carbon in soils, based on archaeological sites during the period from 25 to 2000 years old, with differences in climatic and parent rock qualities, in a region with a thousand-year history of human activity, can be used for the development and implementation of programs for the ecological rehabilitation of degraded land in sub-Mediterranean conditions. The chronofunction of the change in the thickness of soils is especially promising: a logistic type (in connection with the slowing of the rate of pedogenesis over time) must be applied, which allows for the calculation of the rate of the formation of the humus horizon, depending on the morphological status of the soils. The management of the process of reproduction of soil resources involves the use of several standard indicators: permissible erosion losses of the soil, the rate of formation of the humus horizon, the optimum rate of humus formation and humus accumulation, and equivalent doses of organic fertilizers. All these factors may be considered as the most complete and rigorous solution of this problem, as compared with available approaches for determining T-values to ensure resource-saving and ecological farming.

Funding: The work was done in the framework of the implementation of the base part of the state assignment of the Ministry of Education and Science of the Russian Federation for the Belgorod State National Research University on 2019 year.

Acknowledgments: We would like to acknowledge the kind assistance for advisory support on archaeology issues Vladimir Stolba. The manuscript was greatly improved by comments from three anonymous reviewers and is greatly appreciated.

Conflicts of Interest: The authors declare no conflict of interest.

\section{References}

1. Litvin, L.F.; Zorina, Y.F.; Sidorchuk, A.Y.; Chernov, A.V.; Golosov, V.N. Erosion and sedimentation on the Russian Plain, part 1: Contemporary processes. Hydrol. Process. 2003, 17, 3335-3346. [CrossRef]

2. Dolgilevich, M.I. Dust Storms and Agroforestry Activities; Kolos: Moscow, Russia, 1978.

3. Kirkby, M.J. A basis for soil profile modelling in a geomorphic context. J. Soil Sci. 1985, 36, 97-121. [CrossRef]

4. Skidmore, E.L. Soil loss tolerance. In Determinants of Soil Loss Tolerance, special publication 45; American Society of Agronomy and Soil Science Society of America: Madison, WI, USA, 1982; pp. 87-93.

5. Shvebs, H.I. The Theoretical Bases of Erosion Science; Vyisshaya Shkola: Kiev, Ukraine, 1981.

6. Lisetskii, F.N.; Svetlitchnyi, A.A.; Chornyy, S.G. Recent Developments in Erosion Science; Konstanta: Belgorod, Russia, 2012; ISBN 978-5-9786-0248-7. [CrossRef]

7. Elwell, H.; Stocking, M. Estimating soil life-span for conservation planning. Trop. Agric. 1984, 61, $148-150$.

8. Lisetskii, F.N.; Muntian, A.N.; Zholumskaya, K.V. Duration estimating spending soil under active development of erosion processes. Biogeosyst. Tech. 2016, 7, 49-64.

9. Doe, W.W., III; Harmon, R.S. Introduction to soil erosion and landscape evolution modelling. In Landscape Erosion and Evolution Modeling; Kluwer Academic/Plenum Publisher: New York, NY, USA, 2001; pp. 1-14.

10. Jetten, V.G.; Govers, G.; Hessel, R. Erosion models: Quality of spatial predictions. Hydrol. Process. 2003, 17, 887-900. [CrossRef]

11. Lenz, J.; Fritz, M.; Schirrmeister, L.; Lantuit, H.; Wooller, M.J.; Pollard, W.H.; Wetterich, S. Periglacial landscape dynamics in the western Canadian arctic: Results from a thermokarst lake record on a push moraine (Herschel island, Yukon territory). Palaeogeogr. Palaeoclimatol. Palaeoecol. 2013, 381, 15-25. [CrossRef] 
12. Griffith, M.A. A pedological investigation of an archaeological site in Ontario, Canada, I. An examination of the soils in and adjacent to a former village. Geoderma 1980, 24, 327-336. [CrossRef]

13. Ivanov, I.V.; Aleksandrovsky, A.L. Investigation methods of soil evolution. Pochvovedenie 1987, 1, 112-121.

14. Demkin, V.A.; Dergacheva, M.I.; Borisov, A.V.; Ryskov, Y.G.; Oleinik, S.A. Soil evolution and climate change in the semidesert zone of Eastern Europe during the late Holocene. Eur. Soil Sci. 1998, 2, 133-143.

15. Chichagova, O.A.; Krenke, N.A.; Alexandrovskiy, A.L.; Glasko, M.P. Buried soils of floodplains and paleoenvironmental changes in the Holocene. Rev. Mex. Cienc. Geológicas 2004, 21, 9-17.

16. Goleusov, P.V.; Lisetskii, F.N. Soil development in anthropogenically disturbed forest-steppe landscapes. Eur. Soil Sci. 2008, 41, 1480-1486. [CrossRef]

17. Walkington, H. Soil science applications in archaeological contexts: A review of key challenges. Earth Sci. Rev. 2010, 103, 122-134. [CrossRef]

18. Alexandrovskiy, A.L. Holocene development of soils in response to environmental changes: The Novosvobodnaya archaeological site, North Caucasus. Catena 2000, 41, 237-248. [CrossRef]

19. Maher, B.A.; Alekseev, A.; Alekseeva, T. Magnetic mineralogy of soils across the Russian steppe: Climatic dependence of pedogenic magnetite formation. Palaeogeogr. Palaeoclimatol. Paleoecol. 2003, 201, 321-341. [CrossRef]

20. Prikhod'ko, V.E.; Ivanov, I.V.; Manakhov, D.V.; Gerasimenko, N.P.; Inubushi, K.; Nagano, K.; Kawahigashi, M.; Sugihara, S. Soils, vegetation, and climate of the southern transural region in the middle bronze age (by the example of the Arkaim fortress). Eur. Soil Sci. 2013, 9, 925-934. [CrossRef]

21. Peters, S.; Borisov, A.V.; Reinhold, S.; Korobov, D.S.; Thiemeyer, H. Microbial characteristics of soils depending on the human impact on archaeological sites in the Northern Caucasus. Quat. Int. 2014, 324, 162-171. [CrossRef]

22. Saláta, D.; Krausz, E.; Reményi, L.; Kenéz, A.; Peto, Á. Combining historical land-use and geoarchaeological evidence to support archaeological site detection. Agrokem. Talajt. 2014, 1, 99-108. [CrossRef]

23. Chernysheva, E.V.; Korobov, D.S.; Khomutova, T.E.; Borisov, A.V. Urease activity in cultural layers at archaeological sites. J. Archaeol. Sci. 2015, 57, 24-31. [CrossRef]

24. Kern, D.C.; Costa, J.A.; da Silveira, M.I.; de Oliveira, E.R.; Lima Frazão, F.J.; Berredo, J.F.; da Costa, M.L.; Kämpf, N. Pedo-geochemical signatures of archeological sites in the tapirapé-aquiri national forest in Marabá, Amazonia, Brazil. Geoarchaeology 2015, 5, 430-451. [CrossRef]

25. Golyeva, A.; Khokhlova, O.; Lebedeva, M.; Shcherbakov, N.; Shuteleva, I. Micromorphological and chemical features of soils as evidence of bronze age ancient anthropogenic impact (Late Bronze Age Muradymovo settlement, Ural region, Russia). Geosciences (Switz.) 2018, 9, 313. [CrossRef]

26. Mitusov, A.V.; Mitusova, O.E.; Pustovoytov, K.; Lubos, C.C.-M.; Dreibrodt, S.; Bork, H.-R. Palaeoclimatic indicators in buried soils under archaeological monuments in the Eurasian steppe: A review. Holocene 2009, 19, 1153-1160. [CrossRef]

27. Gladfelter, B.G. Developments and directions in geoarchaeology. Adv. Archaeol. Method Theory 1981, 4, 343-364.

28. Opolot, E.; Yu, Y.Y.; Finke, P.A. Modeling soil genesis at pedon and landscape scales: Achievements and problems. Quat. Int. 2015, 376, 34-46. [CrossRef]

29. Birkeland, P.W. Holocene soil chronofunctions, Southern Alps, New Zealand. Geoderma 1984, 34, 115-134. [CrossRef]

30. Heimsath, A.M.; Dietrich, W.E.; Nishiizumi, K.; Finkel, R.C. The soil production function and landscape equilibrium. Nature (Lond.) 1997, 388, 358-388. [CrossRef]

31. Lisetskii, F.N.; Stolba, V.F.; Goleusov, P.V. Modeling of the evolution of steppe chernozems and development of the method of pedogenetic chronology. Eur. Soil Sci. 2016, 49, 846-858. [CrossRef]

32. Lisetskii, F.N.; Stolba, V.F.; Marinina, O.A. Indicators of agricultural soil genesis under varying conditions of land use. Geoderma 2015, 239, 304-316. [CrossRef]

33. Cordova, C. Crimea and the Black Sea: An Environmental History; I.B. Tauris: London, UK; New York, NY, USA, 2016.

34. Lisetskii, F.N.; Stolba, V.F.; Pichura, V.I. Late-holocene palaeoenvironments of southern Crimea: Soils, soil-climate relationship and human impact. Holocene 2017, 27, 1859-1875. [CrossRef]

35. Lisetskii, F.; Zelenskaya, E.; Rodionova, M. Geochemical features of fallow land in ancient plots in the chora of Chersonesos. Geosciences (Switz.) 2018, 8, 410. [CrossRef] 
36. Munsell Color Company. Munsell Soil Color Charts: Year 2000 Revised Washable Edition; GretagMacbeth: New Windsor, NY, USA, 2000.

37. Arinushkina, E.V. Manual for the Chemical Analysis of Soils; University Press: Moscow, Russia, 1970. (In Russian)

38. Smith, R.M.; Stamey, W.L. Determining the range of tolerable erosion. Soil Sci. 1965, 100, 414-424. [CrossRef]

39. Renard, K.G.; Foster, G.R.; Weesies, G.A.; Porter, J.P. RUSLE: Revised universal soil loss equation. J. Soil Water Conserv. 1991, 46, 30-33.

40. Agroclimatic Guide to the Crimean Region; Bogatyr, T.K. (Ed.) Gidrometeoizdat: Leningrad, Russia, 1959. (In Russian)

41. Volobuev, V.R. Introduction to Energetics of Soil Formation; Franklin Book Programs: Cairo, Egypt, 1975.

42. Alexander, E.B. Rates of soil formation: Implications for soil loss tolerance. Soil Sci. 1988, 145, 37-45. [CrossRef]

43. Li, Y.; Bai, X.Y.; Wang, S.J.; Qin, L.Y.; Tian, Y.C.; Luo, G.J. Evaluating of the spatial heterogeneity of soil loss tolerance and its effects on erosion risk in the carbonate areas of southern China. Solid Earth 2017, 3, 661-669. [CrossRef]

44. Zhao, J.; Yang, Z.; Govers, G. Soil and water conservation measures reduce soil and water losses in China but not down to background levels: Evidence from erosion plot data. Geoderma 2019, 337, 729-741. [CrossRef]

45. Buryak, Z.A.; Zelenskaya, E.Y.; Poletaev, A.O.; Tsybenko, V.V. System approach to soil protection and ecological arrangement of watersheds at the regional level, Belgorod oblast. Ecol. Environ. Conserv. 2019, 1, 219-228.

46. Verheijen, F.G.A.; Jones, R.J.A.; Rickson, R.J.; Smith, C.J.; Bastos, A.C.; Nunes, J.P.; Keizer, J.J. Concise overview of European soil erosion research and evaluation. Acta Agric. Scand. Sect. B Soil Plant Sci. 2012, 62 (Suppl. 2), 185-190. [CrossRef]

47. Goleusov, P.V. Soil formation under different combinations of substrate and phytocenotic conditions in the forest-steppe zone. Eur. Soil Sci. 2003, 9, 937-945.

48. Schumm, S.A.; Harvey, M.D. Natural erosion in the USA. In Determinants of Soil Loss Tolerance; special publication 45; American Society of Agronomy and Soil Science Society of America: Madison, WI, USA, 1982; pp. 15-22.

49. Montgomery, D.R. Soil erosion and agricultural sustainability. Proc. Natl. Acad. Sci. USA 2007, 104, 13268-13272. [CrossRef]

50. Bennett, H.H. Soil Conservation; McGraw-Hill, Book Company, Inc.: New York, NY, USA, 1939.

51. Renard, K.G.; Foster, G.R.; Weesies, G.A.; McCool, D.K.; Yoder, D.C. Predicting Soil Erosion by Water. A Guide to Conservation Planning with the Revised Universal Soil Loss Equation RUSLE; USDA Agriculture Handbook No 703; U.S. Department of Agriculture: Washington, DC, USA, 1997.

52. Lal, R. Soil degradation by erosion. Land Degrad. Dev. 2001, 12, 519-539. [CrossRef]

53. Roloff, G.; Larson, G.A.; Larson, W.E.; Voss, R.P.; Becken, P.W. A dual targeting criterion for soil conservation programs in Minnesota. J. Soil Water Conserv. 1988, 1, 99-102.

54. Lima, C.G.R.; Carvalho, M.P.; Souza, A.; Costa, N.R.; Montanari, R. Influence of chemical attributes in erodibility and tolerance of soil loss in watershed of low São José of Dourados River [Influência de atributos químicos na erodibilidade e tolerância de perda de solo na bacia hidrográfica do baixo São José dos Dourados]. Geociencias 2016, 1, 63-76.

55. Di Stefano, C.; Ferro, V. Establishing soil loss tolerance: An overview. J. Agric. Eng. 2016, 3, 127-133. [CrossRef]

56. Duan, X.; Xie, Y.; Liu, B.; Liu, G.; Feng, Y.; Gao, X. Soil loss tolerance in the black soil region of Northeast China. J. Geogr. Sci. 2012, 4, 737-751. [CrossRef]

57. Singh, R.K.; Somasundaram, J.; Lakaria, B.L.; Mandal, D.; Sinha, N.K.; Lal, R. Using credible soil loss tolerance value for conservation planning and managing diverse physiographic regions in Rajasthan. Agric. Res. 2017, 2, 169-178. [CrossRef]

58. Chornyy, S.; Poliashenko, N. Determination of soil-loss tolerance for chernozem of Right-Bank Ukraine. In Soil Science Working for a Living: Applications of Soil Science to Present-Day Problems; Springer: Cham, Switzerland, 2017; pp. 109-119.

59. Kuznetsov, M.S.; Abdulkhanova, D.R. Soil loss tolerance in the central chernozemic region of the European part of Russia. Eur. Soil Sci. 2013, 7, 802-809. [CrossRef]

60. Johnson, L.C. Soil loss tolerance: Fact or myth? J. Soil Water Conserv. 1987, 3, 155-160. 
61. Duan, X.; Shi, X.; Li, Y.; Rong, L.; Fen, D. A new method to calculate soil loss tolerance for sustainable soil productivity in farmland. Agron. Sustain. Dev. 2017, 37, 2. [CrossRef]

62. Buol, S.W.; Hole, F.D.; McCracken, R.J. Soil Genesis and Classification; The Jowa State University Press: Ames, IA, USA, 1973.

63. Lisetskii, F.N. Evaluation of rate of reproduction of soil resources. Sov. Agric. Sci. 1987, 6, $22-25$.

64. Matsumoto, S.; Ogata, S.; Shimada, H.; Sasaoka, T.; Hamanaka, A.; Kusuma, G.J. Effects of pH-induced changes in soil physical characteristics on the development of soil water erosion. Geosciences (Switz.) 2018, 8, 134. [CrossRef]

65. Zaimes, G.N.; Ioannou, K.; Iakovoglou, V.; Kosmadakis, I.; Koutalakis, P.; Ranis, G.; Emmanouloudis, D.; Schultz, R.C. Improving soil erosion prevention in Greece with new tools. J. Eng. Sci. Technol. Rev. 2016, 9, 66-71. [CrossRef]

66. Jenny, H. Factors of Soil Formation: A System of Quantitative Pedology; McGraw-Hill: New York, NY, USA, 1941.

67. Kolmogorov, A.N. Confidence limits for an unknown distribution function. AMS 1941, 12, 461-463. [CrossRef]

68. Olson, K.R.; Ebelhar, S.A.; Lang, J.M. Effects of 24 years of conservation tillage systems on soil organic carbon and soil productivity. Appl. Environ. Soil Sci. 2013, 2013, 617504. [CrossRef]

69. Lisetskii, F.N. Soil reproduction in steppe ecosystems of different ages. Contemp. Probl. Ecol. 2012, 5, 580-588. [CrossRef]

70. Goleusov, P.V. Attractors of humus horizon formation in chernozems. Adv. Curr. Nat. Sci. 2016, 11, 106-110.

71. Goleusov, P.V.; Lisetskii, F.N.; Chepelev, O.A.; Prisniy, A.V. The rate of soil formation in regenerative ecosystems with various combinations of substratum and vegetation conditions. Int. J. Appl. Eng. Res. 2015, $24,45413-45416$.

72. Lisetskii, F.N.; Stolba, V.F.; Ergina, E.I.; Rodionova, M.E.; Terekhin, E.A. Post-agrogenic evolution of soils in ancient Greek land use areas in the Herakleian Peninsula, southwestern Crimea. Holocene 2013, 23, 504-514. [CrossRef]

73. Lisetskii, F.N.; Pavlyuk, Y.V.; Kirilenko, Z.A.; Pichura, V.I. Basin organization of nature management for solving hydroecological problems. Russ. Meteorol. Hydrol. 2014, 39, 550-557. [CrossRef]

74. Amran, M.A. Mapping seagrass condition using google earth imagery. J. Eng. Sci. Technol. Rev. 2017, 10, 18-23. [CrossRef]

75. Bazilevich, N.I.; Titlyanova, A.A. International Biological Programme 19; Cambridge University Press: Cambridge, UK, 1978.

76. Shvebs, H.I. Formation Water Erosion, Sediment Runoff and Their Evaluation; Hydrometeoyzdat: Leningrad, Russia, 1974.

77. Wischmeier, W.H.; Smith, D.D. Predicting Rainfall Erosion Losses: A Guide to Conservation Planning; USDA Agriculture Handbook No 537; U.S. Department of Agriculture: Washington, DC, USA, 1978.

78. Foley, J.A.; Ramankutty, N.; Brauman, K.A.; Cassidy, E.S.; Gerber, J.S.; Johnston, M.; Mueller, N.D.; O'Connell, C.; Ray, D.K.; West, P.C.; et al. Solutions for a cultivated planet. Nature 2011, 1478, 337-341. [CrossRef]

79. Kalinitchenko, V.P. Soil dynamics management. Biogeosyst. Tech. 2016, 4, 284-316. [CrossRef]

80. Fridland, V.M. Chernozems USSR (Ukraine); Kolos: Moscow, Russia, 1981.

81. Shtompel, Y.A.; Lisetskii, F.N.; Sukhanovskii, Y.P.; Strelnikova, A.V. Soil loss tolerance of brown forest soils of northwestern Caucasus under intensive agriculture. Eur. Soil Sci. 1998, 31, 185-190.

82. Kalinitchenko, V.P. Status of the Earth's geochemical cycle in the standard technologies and waste recycling, and the possibilities of its correction by biogeosystem technique method (problem-analytical review). Biogeosyst. Tech. 2016, 2, 115-144. [CrossRef]

83. Batukaev, A.; Kalinitchenko, V.; Glinushkin, A.; Sokolov, M.; Minkina, T.; Andreev, A.; Zinchenko, V.; Mandzhieva, S.; Sushkova, S.; Il'ina, L.; et al. Carbon and heavy metal turnover in a kastanozem complex of South Russia dry steppe. In Geophysical Research Abstracts. 2019 EGU General Assembly; EGU2019-6022; EGU: Göttingen, Germany, 2019; Volume 21.

(C) 2019 by the author. Licensee MDPI, Basel, Switzerland. This article is an open access article distributed under the terms and conditions of the Creative Commons Attribution (CC BY) license (http://creativecommons.org/licenses/by/4.0/). 